\title{
Compilation of analytical methods to characterize and determine chitosan, and main applications of the polymer in food active packaging Recopilación de métodos analíticos para la caracterización y determinación del quitosano y las principales aplicaciones del polímero en los envases activos alimentarios
}

M.A. Lago , A. Rodríguez Bernaldo de Quirós, R. Sendón , A. Sanches-Silva , H.S. Costa , D.I. Sánchez-Machado , J. López-Cervantes , H. Soto Valdez , G.P. Aurrekoetxea, I. Angulo \& P. Paseiro Losada

To cite this article: M.A. Lago , A. Rodríguez Bernaldo de Quirós, R. Sendón , A. Sanches-Silva , H.S. Costa , D.I. Sánchez-Machado, J. López-Cervantes , H. Soto Valdez, G.P. Aurrekoetxea , I. Angulo \& P. Paseiro Losada (2011) Compilation of analytical methods to characterize and determine chitosan, and main applications of the polymer in food active packaging Recopilación de métodos analíticos para la caracterización y determinación del quitosano y las principales aplicaciones del polímero en los envases activos alimentarios, CyTA - Journal of Food, 9:4, 319-328, DOI: 10.1080/19476337.2011.603844

To link to this article: https://doi.org/10.1080/19476337.2011.603844

\section{(2) Copyright Taylor and Francis Group, LLC}

\section{View supplementary material $\widetilde{ }$}

Published online: 04 Nov 2011.

Submit your article to this journal $₫$

Џll Article views: 3506 


\title{
Compilation of analytical methods to characterize and determine chitosan, and main applications of the polymer in food active packaging
}

\section{Recopilación de métodos analíticos para la caracterización y determinación del quitosano y las principales aplicaciones del polímero en los envases activos alimentarios}

\author{
M.A. Lago ${ }^{\mathrm{a}}$, A. Rodríguez Bernaldo de Quirós $^{\mathrm{a}}$, R. Sendón ${ }^{\mathrm{a}}$, A. Sanches-Silva ${ }^{\mathrm{b}}$, H.S. Costa ${ }^{\mathrm{b}}$, \\ D.I. Sánchez-Machado ${ }^{\mathrm{c}}$, J. López-Cervantes ${ }^{\mathrm{c}}$, H. Soto Valdez ${ }^{\mathrm{d}}$, G.P. Aurrekoetxea ${ }^{\mathrm{e}}$, I. Angulo ${ }^{\mathrm{e}}$ and \\ P. Paseiro Losada*
}

${ }^{a}$ Faculty of Pharmacy, Department of Analytical Chemistry, Nutrition and Food Science, University of Santiago de Compostela, Santiago de Compostela 15782, Spain; ${ }^{b}$ Departamento de Alimentação e Nutrição, Instituto Nacional de Saúde Doutor Ricardo Jorge, I.P., Av. Padre Cruz, 1649-016 Lisboa, Portugal; ${ }^{c}$ Departamento de Biotecnología y Ciencias alimentarias, Instituto Tecnológico de Sonora, P.O. Box 541, Cd. Obregón, Sonora, México; ${ }^{d}$ Centro de Investigación en Alimentación y Desarrollo, A.C., CTAOV, Apdo. Postal 1735, Hermosillo, 83000, Sonora, México; ${ }^{e}$ Gaiker, Technological Center, Parque tecnológico Edificio 202, 48170 Zamudio, Spain

(Received 13 May 2011; final version received 5 July 2011)

\begin{abstract}
Antimicrobial films for food packaging applications have received increasing attention from the industry in recent years. Due to their exceptional properties, such as non-toxicity, biodegradability, antimicrobial characteristics, and biocompatibility, chitosan has proven useful for the development of active materials. This review aims to provide an overview of the main techniques used for the characterization of chitin and chitosan, including Fourier transform infrared spectroscopy (FTIR), ${ }^{1} \mathrm{H}$ and ${ }^{13} \mathrm{C}$ nuclear magnetic resonance (NMR) spectroscopy, UV spectrophotometry, viscosimetry, elemental analysis, X-ray diffraction (XRD), thermogravimetric analysis (TGA), titrations, scanning electron microscopy (SEM) and size exclusion chromatography (SEC) among others. In addition, the main applications of the polymer in food packaging are also reported.
\end{abstract}

Keywords: review; chitosan; chitin; characterization; analytical techniques; food packaging materials; applications

En los últimos años los films antimicrobianos han recibido una gran atención por parte de la industria para su aplicación en el envasado alimentario. Debido a sus excepcionales propiedades, no-tóxico, biodegradable, características antimicrobianas y biocompatible, el quitosano ha demostrado ser útil para el desarrollo de materiales activos. Este artículo de revisión tiene por objeto proporcionar una visión general de las principales técnicas usadas para la caracterización de quitina y quitosano incluidas la espectroscopia infrarroja (FTIR), la espectroscopia RMN de ${ }^{1} \mathrm{H}$ y ${ }^{13} \mathrm{C}$, la espectrofotometría UV, viscosimetría, análisis elemental, difracción de rayos-X (XRD), análisis termogravimétrico (TGA), titulaciones, microscopía electrónica de barrido (SEM) y cromatografía de exclusión por tamaños (SEC) entre otras. Además, se describen las principales aplicaciones del polímero en el envasado de los alimentos.

Palabras clave: revisión; quitosano; quitina; caracterización; técnicas analíticas; materiales para el envasado alimentario; aplicaciones

\section{Introduction}

Chitin is the most abundant polysaccharide after cellulose; although it may have different origins, such as exoskeletons of crustacean, molluscs, insects, and fungi, the main source for obtaining this polysaccharide is the shell of crustaceans (Al Sagheer, Al-Sughayer, Muslim, \& Elsabee, 2009). Among the derivatives of chitin, chitosan has attracted the attention of the scientists due to its numerous applications in various fields, including cosmetics, pharmacy, food, agriculture, and biomedical and material sciences (Abdou, Nagy, \& Elsabee, 2008; Al Sagheer et al., 2009; Kurita,
2006). Chitosan (CAS No.: 9012-76-4), a linear polymer of $(1,4)$-linked 2-amino-deoxy- $\beta$-D-glucan is obtained by partial deacetylation of chitin (Dutta, Tripathi, Mehrotra, \& Dutta, 2009). The process to obtain chitin from the shells of crustaceans basically consists of the following steps: acidic treatment to remove inorganic compounds such as calcium carbonate, followed by an alkaline treatment with $\mathrm{NaOH}$ to solubilize proteins, and finally, controlling the temperature as well as the $\mathrm{NaOH}$ concentration, which is crucial to achieve a satisfactory outcome (Al Sagheer et al., 2009; Rinaudo, 2006). Besides this chemical

*Corresponding author. Email: perfecto.paseiro@usc.es 
procedure to extract chitin, a biological method that involves the use of microorganisms has been reported in the literature (Al Sagheer et al., 2009). Once these steps have been completed, the chitosan was obtained from the chitin by deacetylation using a $\mathrm{NaOH}(40 \%$ wt) solution with $\mathrm{NaBH}_{4}$ (Paulino, Simionato, Garcia, \& Nozaki, 2006).

The degree of acetylation (DA) determines the solubility and reactivity of chitosan, and the molecular weight $\left(M_{w}\right)$ influences the physico-chemical and biological properties; therefore, determining these chemical characteristics is essential to characterize the polysaccharide (Duarte, Ferreira, Marvão, \& Rocha, 2002; Nguyen, Hisiger, Jolicoeur, Winnik, \& Buschmann, 2009). Some of the techniques commonly used for determining the chemical characteristics are IR spectroscopy, ${ }^{1} \mathrm{H}$ and ${ }^{13} \mathrm{C}$ nuclear magnetic resonance (NMR) spectroscopy, UV spectrophotometry, potentiometric titration, elemental analysis, and size exclusion chromatography (SEC).

Due to the excellent properties, such as nontoxicity, biodegradability, biocompatibility, antimicrobial and biofunctional characteristics, the development of chitosan-based materials has received much attention not only in the biomedical area but also in the field of food contact materials (Dutta et al., 2009). In recent years, numerous research works have been addressed to develop antimicrobial food packaging systems to improve food quality and safety. This review is focused on the main analytical techniques used for the characterization of chitin and chitosan; moreover, an overview of the major applications of chitosan-based active food packaging systems is also provided.

\section{Analytical techniques for chitosan characterization}

Since the functional properties of chitin and chitosan are related with the DA, estimating the DA is essential to characterize the samples of chitin and chitosan. Knowledge of the DA allows us to predict the numerous properties of these two polymers (Kasaai, 2009). As it has been mentioned previously, several techniques have been used for this purpose. Each technique presents its advantages and disadvantages; it is generally accepted that a unique technique cannot be used to cover the entire range of the DA (Brugnerotto et al., 2001).

In this review, the main techniques used to characterize chitin and chitosan samples are commented on.

\section{Fourier transform infrared spectroscopy (FTIR)}

Infrared (IR) spectroscopy is widely used because of its simplicity, rapidity, it is non-destructive to the samples and it is not necessary dissolve the sample in aqueous solutions; however, other problems associated with spectroscopic techniques, such as broadening of a peak and overlapping of two or more peaks which leads to incorrect results, are often detected. This technique is appropriate for qualitative study; when quantitative analysis is performed, it is necessary to carry out some complex procedures, such as statistical analysis of several absorption ratios.

When spectroscopic techniques are employed to determine the DA, several aspects must be taken into account to obtain reliable results. These aspects include selecting a suitable measuring and reference band and drawing a good baseline. In addition, sample analysis could be affected by the procedure employed to obtain the chitosan, the experimental conditions and even the equipment used (Fernández Cervera et al., 2004).

Various procedures to determine the degree of $\mathrm{N}$-acetylation in chitin and chitosan samples using IR spectroscopy are reviewed in Kasaai (2008).

Different approaches have been described to calculate the DA. The first one consists of the evaluation of the ratio of absorbance of the probe band (determination of the $\mathrm{N}$-acetyl or amine content) and the absorbance of a reference band; the intensity of this band does not vary with the DA. The DA of an unknown sample can be calculated by comparing the value of the ratio with similar ratio of samples with known DA. Determination of DA can also be performed based on linear calibration plots of the absorption ratio of chitin or chitosan samples with a known DA against their DA; the DA was calculated using IR spectroscopy or an absolute technique such as ${ }^{1} \mathrm{H}$ NMR. The DA of the unknown samples was determined from the equation of the calibration curve. Another approach involves the analysis of various absorption band ratios by means of a statistical method (Kasaai, 2008).

Regarding the reference bands, because the spectrum of chitin or chitosan varies depending on the DA, we cannot use a single reference band for the entire range of DA. Different absorption bands have been reported in the literature, for instance, the $\mathrm{O}-\mathrm{H}$ stretching band at $3450 \mathrm{~cm}^{-1}$, the $\mathrm{C}-\mathrm{H}$ stretching band at $2870 \mathrm{~cm}^{-1}, \mathrm{CH}_{2}$ bending band at $1420 \mathrm{~cm}^{-1}$, $\mathrm{C}-\mathrm{O}$ stretching band at $1030-1070 \mathrm{~cm}^{-1}$, and amide III band at $1315-1320 \mathrm{~cm}^{-1}$ among others.

It is not easy to select a band; each band has its advantages and drawbacks. Thus, for instance, even if the band that corresponds to $\mathrm{OH}$ exhibits a high intensity, some interference could occur due to the $\mathrm{OH}$ group of water, which appears in this region, or a broad peak could be also observed as a result of the involvement of the $\mathrm{OH}$ in intra- and intermolecular hydrogen bonds. To avoid this drawback, it is crucial to use well-dried samples.

In case of the $\mathrm{C}-\mathrm{H}$ stretching band, water does not interfere with the peak, but however, the position of the $\mathrm{C}-\mathrm{H}$ in $N$-acetyl groups varies with the DA. Domard and Rinaudo (1983) used the stretching band $\mathrm{C}-\mathrm{H}$ at $2867 \mathrm{~cm}^{-1}$ to evaluate chitosan samples with 
a $\mathrm{DA}<10$, and satisfactory results were achieved; these authors also pointed out that the $\mathrm{O}-\mathrm{H}$ at $3450 \mathrm{~cm}^{-1}$ reference band is suitable for samples with a $\mathrm{DA}>10$.

Depending on the DA range of the samples, several absorption bands' ratios have been applied.

Shigemasa, Matsuura, Sashiwa, and Saimato (1996) applied these absorption ratios, $\mathrm{A}_{1560} / \mathrm{A}_{1070}$ and $\mathrm{A}_{1560} / \mathrm{A}_{1030}$, to estimate the $\mathrm{DA}$ in different acetylated chitosan derivatives and mixtures of chitin and chitosan; the authors found a good agreement with the results obtained using IR spectroscopy and those obtained using ${ }^{1} \mathrm{H}$ NMR spectroscopy for the whole range of DA.

Mima, Miya, Iwamoto, and Yoshikawa (1983) achieved excellent results in samples highly acetylated with the absorption ratio $\mathrm{A}_{1655} / \mathrm{A}_{2875}$; however, the authors found that the peak corresponding at $1655 \mathrm{~cm}^{-1}$ was not observed in samples with a high DA.

Brugnerotto et al. (2001) evaluated two absorption ratios, $3350 \mathrm{~cm}^{-1}$ and $1420 \mathrm{~cm}^{-1}$ were selected as reference bands and $1320 \mathrm{~cm}^{-1}$ as measuring band. ${ }^{1} \mathrm{H}$ NMR and ${ }^{13} \mathrm{C}$ NMR were used as reference methods for samples with low and high values of DA, respectively. The authors concluded that the absorption ratio $\mathrm{A}_{1320} / \mathrm{A}_{1420}$ is better than $\mathrm{A}_{1320} /$ $\mathrm{A}_{3550}$ since it is only sensitive to the chemical composition of the chitin or chitosan and is independent of the technique employed and the state of the sample.

Khan, Peh, and Ch'ng (2002) evaluated three analytical methods, hydrogen bromide titrimetry, IR spectroscopy, and first derivative UV spectrophotometry, to determine the degree of deacetylation (DD) of chitosan. To perform the IR analysis, samples were prepared in two forms, as potassium bromide $(\mathrm{KBr})$ disks and as films. An absorption ratio of $\mathrm{A}_{1655} / \mathrm{A}_{3450}$ was employed, $1655 \mathrm{~cm}^{-1}$ corresponds to the amide I band and was used as a measure of the $N$-acetyl group content and $3450 \mathrm{~cm}^{-1}$ corresponds to the $\mathrm{O}-\mathrm{H}$ band. Regarding the IR analysis, the authors obtained different values of the DD depending on the state of the sample; higher values were obtained using the films.

The use of IR spectroscopy together with a more complex technique as ${ }^{13} \mathrm{C}$ cross-polarisation magic angle spinning (CP/MAS) NMR spectroscopy to determine the DA of chitin and chitosan samples has been reported by Duarte et al. (2002). ${ }^{13} \mathrm{C} \mathrm{CP} / \mathrm{MAS}$ NMR spectroscopy was used as the reference method. To choose the best absorption ratio (A $\mathrm{A}_{\text {Probe Band (Baseline) }}$ $\left.\mathrm{A}_{\text {Reference Band (Baseline) }}\right)\left(\mathrm{A}_{\mathrm{PB}(\mathrm{BL})} / \mathrm{A}_{\mathrm{RB}(\mathrm{BL})}\right)$, a statistical study based on a regression model was conducted; the authors found that the best absorption ratios were the following: $A_{1626(B L 2)} / A_{2877(B L 5)},\left(A_{1663(B L 2)}+\right.$ $\left.\mathrm{A}_{1626(\mathrm{BL} 2)}\right) / \mathrm{A}_{2877(\mathrm{BL} 5)}, \quad \mathrm{A}_{1561(\mathrm{BL} 2)} / \mathrm{A}_{1074(\mathrm{BL} 6)}, \quad$ and $\mathrm{A}_{1561(\mathrm{BL})} / \mathrm{A}_{1025(\mathrm{BL} 6)}$.
Near IR (NIR) was employed by Vårum, Egelandsdal, and Ellekjaer (1995) to characterize fully water-soluble chitosans with degrees of acetylation from $1 \%$ to $51 \%$ in free amine form as well as in four different salt forms (formate, acetate, propionate, and chloride). With the aim to establish spectral data-salt form and physico-chemical properties of chitosan relationships, a statistical analysis founded on multivariate regression method was carried out. With the proposed method, the acetylation degree could be predicted for samples with a DA from $0 \%$ to $50 \%$.

IR spectroscopy is also a suitable technique to differentiate between $\alpha$ - and $\beta$-chitin. On one hand, in the spectra of $\alpha$-chitin, the amide I band splits at $1660 \mathrm{~cm}^{-1}$ due to the intermolecular hydrogen bond $\mathrm{CO}-\mathrm{NH}$ and at $1625 \mathrm{~cm}^{-1}$ because of the intramolecular hydrogen bond $\mathrm{CO}-\mathrm{HOCH}_{2}$, whereas in the $\beta$-chitin spectrum only one band at $1656 \mathrm{~cm}^{-1}$ is detected. On the other hand, an intense band at $1430 \mathrm{~cm}^{-1}$ is observed in the spectrum of $\beta$-chitin, and a band at $1416 \mathrm{~cm}^{-1}$ in the $\alpha$-chitin spectrum. In addition, the bands at $3264 \mathrm{~cm}^{-1}$ and $3107 \mathrm{~cm}^{-1}$ are perfectly detected in the $\alpha$-chitin spectrum but, however, are very weak in the $\beta$-chitin spectra. Another important difference are the bands at $703 \mathrm{~cm}^{-1}$ and $750 \mathrm{~cm}^{-1}$, which are perfectly resolved in the $\alpha$-chitin spectrum, while in the $\beta$-chitin, the bands that occur at $682 \mathrm{~cm}^{-1}$ and $710 \mathrm{~cm}^{-1}$ are not well defined (Al Sagheer et al., 2009).

\section{Nuclear magnetic resonance}

For quantitative analysis, NMR spectroscopy either liquid-state ${ }^{1} \mathrm{H}$ NMR for soluble samples or solid-state ${ }^{13} \mathrm{C}$ NMR is the preferred method because of its simplicity, quickness, and accuracy. Moreover, the American Standard Test Method organization has selected the ${ }^{1} \mathrm{H}$ NMR as the standard method for the determination the DA in chitosan samples (Kasaai, 2008; Rinaudo, 2006). In case of ${ }^{13} \mathrm{C}$ NMR spectroscopy, although it is not necessary to dissolve the samples, it is essential that the samples are highly pure to obtain suitable spectrum (Fernández Cervera et al., 2004).

Samples of chitin and chitosan obtained from silkworm crysalides were characterized in a study conducted by Paulino et al. (2006). Several techniques were used among them: Fourier transform infrared spectroscopy (FTIR) and ${ }^{13} \mathrm{C}$ NMR spectroscopy. When the ${ }^{13} \mathrm{C}$ NMR spectra of chitin and chitosan were compared, it was observed that the peaks corresponding to $\mathrm{CH}_{3}$ and $\mathrm{C}=\mathrm{O}$ groups have disappeared in the spectra of chitosan due to the deacetylation of chitin. With regard to the FTIR study, a peak at $1626 \mathrm{~cm}^{-1}$ appears in the spectrum of a chitin sample in a crystalline state, while in the spectra of the chitosan samples, two bands at $1626 \mathrm{~cm}^{-1}$ and 
another at $1656 \mathrm{~cm}^{-1}$ were observed, which could be attributed to the amorphous state of the samples.

Fernández Cervera et al. (2004) used the solid-state ${ }^{13} \mathrm{C}$ NMR to estimate the DA of chitosans obtained from lobster chitin. The calculation was performed according the equation $\mathrm{DA}=I_{\mathrm{CH} 3} / I_{\mathrm{C} 1}+I_{\mathrm{C} 2}+I_{\mathrm{C} 3}+$ $I_{\mathrm{C} 4}+I_{\mathrm{C} 5}+I_{\mathrm{C} 6} / 6$, where $\left(I_{\mathrm{C} 1} ; I_{\mathrm{C} 2} ; I_{\mathrm{C} 3} ; I_{\mathrm{C} 4} ; I_{\mathrm{C} 5} ; I_{\mathrm{C} 6}\right)$ are the relative intensities of the resonance of the ring carbon and $\left(I_{\mathrm{CH} 3}\right)$ is the methyl carbon obtained by ${ }^{13} \mathrm{C}$ NMR. From the spectrum, it could be observed that in the polymeric chain of chitosans, peaks corresponding to methyl and carbonyl are related with the monomeric form of chitin, indicating that the original chitin is not completely deacetylated.

Abdou et al. (2008) applied the ${ }^{1} \mathrm{H}$ NMR spectroscopy to determine the DD of samples of chitosan obtained from different sources. Samples were dissolved in $\mathrm{D}_{2} \mathrm{O}$ acidified with $\mathrm{DCL}$ to improve solubility. The ${ }^{1} \mathrm{H}$ NMR spectra of chitosan showed the characteristic peaks: peak at $4.9 \mathrm{ppm}$ that corresponds to $\mathrm{C} 1$ proton of glucosamine unit in chitosan, the peaks at 3-4 ppm that correspond to $\mathrm{C} 2-\mathrm{C} 6$ protons of glucosamine and $\mathrm{N}$-acetylglucosamine units; the peak at $2.06 \mathrm{ppm}$ that corresponds to amide methyl protons and at $2.21 \mathrm{ppm}$ for acetic acid moiety. The DD was calculated according to the method of Lavertu et al. (2003), degree of deacetylation (DDA) $(\%)=\left(\mathrm{H}_{4.9} / \mathrm{H}_{4.9}+\mathrm{H}_{2.06 / 3}\right) \times 100$.

Al Sagheer et al. (2009) also used the ${ }^{1} \mathrm{H}$ NMR spectroscopy to characterize the samples of chitin and chitosan from marine sources. Samples were prepared in $2 \%$ deuterated acetic acid in $\mathrm{D}_{2} \mathrm{O}$ solution. No peak between 1.0 and 1.5, corresponding to methyl proton resonance from protein, was observed, which indicates that the chitin sample is highly pure.

\section{Viscosimetry}

The viscosimetry is one of the most widely used methods for the characterization of chitosan (Anthonsen, Vårum, \& Smidsrød, 1993; Errington, Harding, Vårum, \& Illum, 1993; Gamzazade et al., 1985; Kasaai, Arul, \& Charlet, 2000; Kucukgulmez et al., 2011; Ottøy, Vårum, Christensen, Anthonsen, \& Smidsrød, 1996; Pochanavanich \& Suntornsuk, 2002; Pogodina et al., 1986; Rao, 1993; Rinaudo, Milas, \& Dung, 1993; Roberts \& Domszy, 1982; Van Toan, 2009; Wang, Bo, Li, \& Qin, 1991; Yomota, Miyazaki, \& Okada, 1993). Viscosity is a crucial parameter for the quality of chitosan (Van Toan, 2009), being closely related to the DA (Kucukgulmez et al., 2011).

According to the Mark-Houwink-Sakurada (MHS) equation, the intrinsic viscosity $[\eta]$ of a polymer solution is related to the polymer molecular weight (Flory, 1953; Tanford, 1961):

$$
[\eta]=K M_{v}^{a}
$$

where $M_{v}$ is the viscosity average molecular weight, and $K$ and $a$ are empirical constants settled by solutesolvent system and temperature (Ottøy et al., 1996).

Data series of different polymers, with known molecular weights, shall be required to determinate these coefficients, $K$ and $a$. Several works obtained different values of $K$ and $a$ for chitosan in different solvents (Anthonsen et al., 1993; Errington et al., 1993; Gamzazade et al., 1985; Pogodina et al., 1986; Rao, 1993; Rinaudo et al., 1993; Roberts \& Domszy, 1982; Wang et al., 1991; Yomota et al., 1993).

Usually, $M_{v}$ is not experimentally accessible, therefore, other parameters are being used. These alternatives are $M_{n}$ (number average molecular weight), $M_{w}$ (weight average molecular weight) or $M_{z}$ (diffusion average molecular weight). Many authors use either of them in MHS equation, ignoring polydispersity effects. (Kasaai et al., 2000).

To use $M_{w}$, polydispersity effects must be considered. In order to be included in the MHS equation, we introduce the polydispersity correction factor $q_{\mathrm{MHS}}$ :

$$
[\eta]=K q_{\mathrm{MHS}} M_{w}^{a}
$$

The value of $q_{\text {MHS }}$ oscillates between samples, and its value can differ from the value obtained by SEC (Kasaai et al., 2000). $q_{\text {MHS }}$ is function of $a, M_{w}, M_{n}$, and $M_{z}$ and can be evaluated according to the method proposed by Manaresi, Munari, Pilati and Marianucci (1988):

$$
q_{\mathrm{MHS}}=\left(M_{w} / M_{n}\right)^{b}\left(M_{z} / M_{w}\right)^{c}
$$

where the constant $c$ depends only on $a$, while the constant $b$ depends on $a$ as well as $M_{z} / M_{w}$ (Guaita et al., 1991).

\section{UV spectrometry}

This method is very useful to characterize chitosan derivatives because the chitosan presents no absorption peak in the range $200-400 \mathrm{~nm}$, but most of their products present a characteristic peak in this range. This method along with the FTIR data gives us a good form of characterization (Ma, Qian, Yang, Hu, \& Nie, 2010; Wang, Jin, \& Chang, 2009).

In crude chitosan samples, the presence of protein is very common, which can cause interference and will lead to wrong data of the DA. The first derivative UVspectrophotometry (1DUVS) could be an appropriate method for the determination of DA in this type of samples, due to the interference protein are located at $280 \mathrm{~nm}$, and with this method we measured at $203 \mathrm{~nm}$ (Tan, Khor, Tan, \& Wong, 1998).

\section{Titrations}

Different types of titration have been used with chitosan: isothermal titration calorimetry (ITC) (Kim, 
2004), turbidimetric titration (Rosca, Popa, Lisa, \& Chitanu, 2005), acid-base titration (Arcidiacono \& Kaplan, 1992; Sannan, Kurita, \& Iwakura, 1976), conductimetric titration (de Alvarenga, de Oliveira, \& Bellato, 2010; dos Santos, Caroni, Pereira, da Silva, \& Fonseca, 2009; Rosca et al., 2005), and potentiometric titration (Abdou et al., 2008; Cai et al., 2006; Gyliene, Rekertas, \& Salkauskas, 2002; Kucukgulmez et al., 2011; Li et al., 2005; Liu, Bao, Du, Zhou, \& Kennedy, 2006; Pochanavanich \& Suntornsuk, 2002; Pourjavadi, Mahdavinia, Zohuriaan-Mehr, \& Omidian, 2003; Rogovina, Akopova, \& Vichoreva, 1998; Rosca et al., 2005; Song, Zhang, Gao, \& Ding, 2011; Zhang, Xue, Xue, Gao, \& Zhang, 2005; Zhang, Zhang, Ding, Zhang, \& Liu, 2011).

With ITC, thermodynamic bindings can be determined through measurements of the molecular interactions' energy at constant temperatures. ITC provides the number of binding sites of chitosan, its binding constant, and the enthalpy of binding (Kim, 2004).

Turbidimetric assessments are an interesting method because in conjunction with other measurements obtained with potentiometric or conductimetric titrations, we could get the profile of interactions that occur between molecules (Rosca et al., 2005).

Acid-base, conductimetric, and potentiometric titrations are similar. In all cases, chitosan is dissolved in an acid to be titrated with a base (the groups $\mathrm{NH}_{3}{ }^{+}$) or vice versa; and the end point of titration is measured with an indicator, the solution conductance, or with the voltage across the analytes. The sample DD derives from the volume of base consumed in the reaction and its concentration. With this data, we can get the DD of chitosan samples from different formulas like those proposed by Broussignac (1968), Donald and Hayes (1988), or Pourjavadi et al. (2003).

However, these techniques have limitations such as lack of solubility, the necessary drying of the samples, and the essential correction of mathematical models of the calibration curves to align correctly the results (Balázs \& Sipos, 2007). But the low price of its performance makes it an extremely used technique.

\section{Ninhydrin test}

This test is used to determine the amount of chitosan by quantification of free amino groups of the glycoside units of chitosan. It is based on a colorimetric reaction where the ninhydrin reacts with the primary amino groups to form a colored product, diketohydrindylidene-diketohydrindamine, which can be measured at $570 \mathrm{~nm}$ in a spectrophotometer (Curotto \& Aros, 1993; Prochazkova, Vårum, \& Ostgaard, 1999; Wei, Cruz, \& Gorski, 2002). Its main advantage is the use of a minimal amount of sample (Tan et al., 1998).
With this method, the DD can also be obtained with the amount of chitosan determined $(\phi)$ and the sample mass $(W)$ (Tan et al., 1998):

$$
D D=\phi /[(W-161 \phi) /(204+\phi)] \times 100
$$

\section{Thermogravimetric analysis ( $T G A)$}

The first characterizations of chitin and chitosan set aside the thermal stability of these polysaccharides; but in recent years, many authors studied these chitosan/ chitin characteristics (Abdou et al., 2008; Al Sagheer et al., 2009; Gartner, Peláez, \& López, 2010; Hong et al., 2007; López, Mercè, Alguacil, \& López-Delgado, 2008; Neto et al., 2005; Pawlak \& Mucha, 2003; Paulino et al., 2006; Popa, Lisa, \& Aelenei, 2008; Taboada, Cabrera, \& Cárdenas, 2004).

Everyone found two typical degradations between $50^{\circ} \mathrm{C}-100^{\circ} \mathrm{C}$ and $250^{\circ} \mathrm{C}-400^{\circ} \mathrm{C}$; the first is caused due to the loss of water from the bonds of polysaccharide chains, and the second by the depolymerization of the polysaccharide with the consequent loss of volatile compounds. In some cases, a new point of degradation appears at about $350^{\circ} \mathrm{C}-550^{\circ} \mathrm{C}$, due to new residual cross-linked molecules from degradation of chitosan (Gartner et al., 2010; López et al., 2008; Paulino et al., 2006). In many cases after the thermal analysis there are residues, these are mineral impurities from the raw material (Paulino et al., 2006).

From these studies, we can affirm that the conformation of $\alpha$-chitin is more thermally stable than $\beta$-chitin (Al Sagheer et al., 2009), and the chitin is more thermally stable than chitosan (Abdou et al., 2008).

\section{Differential scanning calorimetry (DSC)}

Differential scanning calorimetry (DSC) and thermogravimetric analysis (TGA) are two complementary techniques. In fact, DSC results confirm the TGA results, on the typical degradations of chitosan and chitin. About $70^{\circ} \mathrm{C}$, an endothermic peak produced by the evaporation of absorbed water was found. Also, around $280-300^{\circ} \mathrm{C}$, an exothermic peak is triggered by the decomposition of amine residues of chitosan chains (Fernández Cervera et al., 2004; Guinesi, Gomes, \& Cavalheiro, 2006; Neto et al., 2005). This decomposition has two steps, the first one starts a random split of the glycoside bonds, and then acetic and butyric acid and short-chain fatty acids are formed (López et al., 2008).

Likewise, using TGA, some authors found a third peak, an exothermic peak at $400^{\circ} \mathrm{C}$ caused by degradation of acetyl residues (more stable than amine residues). Signal's peak areas or heights have been used to estimate the DA. The data obtained from DSC were consistent with the DA determined by NMR techniques (Guinesi et al., 2006). 


\section{Elemental analysis}

This is a destruction method in which we can determine the percentages of $\mathrm{C}, \mathrm{N}, \mathrm{H}$ and $\mathrm{O}$ of the polymer sample (Abdou et al., 2008; Aiba, 1986; Al Sagheer et al., 2009; Kasaai, Arul, Chin, \& Charlet, 1999; Kasaai et al., 2000; Kim, Kim, \& Lee, 1996; Kucukgulmez et al., 2011; Rúnarsson et al., 2010; Taboada et al., 2004).

With the combustion of the sample at $1000^{\circ} \mathrm{C}$ and a flow rate of $100 \mathrm{ml} / \mathrm{min}$ of helium (Kim et al., 1996), we get the ratio $\mathrm{N} / \mathrm{C}$ that can be included in the equation of Kasaai et al. (1999) to obtain the DA of the samples.

$$
\mathrm{DA}=\frac{\frac{N}{C}-5145}{6861-5145} \times 1000
$$

With this ratio $(\mathrm{N} / \mathrm{C})$, we can also obtain the degree of substitution (DS) in chitosan derivates, according to Inukai's equation (Inukai, Chinen, Matsuda, Kaida, \& Yasuda, 1998).

$$
\mathrm{DS}=\frac{\left(\frac{C}{N}\right)-\left(\frac{C}{N}\right) 0}{n}
$$

where $C / N$ is the ratio $(\mathrm{w} / \mathrm{w})$ of carbon to nitrogen of chitosan derivative, $(C / N)$ o is the ratio $(\mathrm{w} / \mathrm{w})$ of carbon to nitrogen of the original chitosan, and $n$ is the number of carbons introduced after chitosan derivative.

\section{Size exclusion chromatography (SEC)}

Besides the DA, the molecular weight influences the biological and physicochemical properties of chitosan; thus, estimating these parameters is crucial to characterize the polysaccharide. Since the chitosan samples are hugely heterogeneous and are present in a wide range of molecular weight, selecting an appropriate column to perform SEC is a crucial step to achieve satisfactory results (Nguyen et al., 2009).

Ottøy et al. (1996) carried out a study to characterize the molecular weight as well as to evaluate the molecular weight distributions of the fractions of two chitosan samples with a DA of 15 and 52. First, the samples were fractionated by preparative SEC. To perform the assay, a system consisting of two columns in series $(9 \times 95 \mathrm{~cm})$ packed with Sepharose CL-6B and Sepharose CL-4B, respectively, was used. Then, the fractions were analyzed by analytical SEC coupled to an on-line, low-angle laser light scattering detector and a differential refractive index detector. Analytical conditions were as follows: two different stationary phases were evaluated, the first system included two columns in series (TSK G6000-PW and TSK G5000$\mathrm{PW}$, internal diameter (ID) $=7.5 \mathrm{~mm}$, length $(\mathrm{l})=$ $600 \mathrm{~mm}$ ), and the second one consisted of columns (Pharmacia HR 10130, ID = $10 \mathrm{~mm}, \mathrm{Il}=300 \mathrm{~mm}$ ) with a packaging of macroporous, monodisperse $(15 \mu \mathrm{m})$, and hydrophilic polymer particles with very large pores. Both systems were protected by a guard column (TSK Guard PWH column, ID $=7.5 \mathrm{~mm}$, $1=75 \mathrm{~mm}$ ). The mobile phase was composed of $0.2 \mathrm{M}$ ammonium acetate, of $\mathrm{pH}$ 4.5. The flow rate and injection volume were $0.4 \mathrm{ml} / \mathrm{min}$ and $200-1750 \mu \mathrm{l}$ according to the sample concentration, respectively. With the proposed conditions, the fractions of the two chitosan samples were well separated.

A similar procedure was employed by Nguyen et al. (2009); the authors pointed out that semi-preparative SEC prior to analysis plays a key role in obtaining homogeneous samples, which is essential to accurately calculate the molecular weight.

A system to estimate the degree of $N$-acetylation and simultaneously the molecular weight of chitosan samples by using gel permeation chromatography coupled to ultraviolet spectrometry was developed by Aiba (1986). The method is founded on the measurement of UV absorbance at $220 \mathrm{~nm}$ of acetamide groups. The analysis was performed on a Shimpack DIOL-300 column and using a mobile phase consisting of an aqueous solution containing $0.01 \mathrm{M}$ acetic acid and $0.2 \mathrm{M}$ sodium chloride at a flow rate of $1 \mathrm{ml} / \mathrm{min}$. The results obtained with this method are in good agreement with those obtained by other methods.

Pochanavanich and Suntornsuk (2002) used an ultralinear hydrogel column $\left(10^{3}-2 \times 10^{7}\right.$ Da) to determine the molecular weights of fungal chitosan. The calibration curve was constructed within the range of $5.8 \times 10^{3}-1.6 \times 10^{6} \mathrm{Da}$. The results indicated that the molecular weight of fungal chitosan was lower than that of chitosan obtained from crab shells.

\section{Light scattering}

Dynamic light scattering and static light scattering are useful methods for the characterization of chitosan in solution (Kjøniksen, Iversen, Nyström, Nakken, \& Palmgren, 1998; Pa \& Yu, 2001; Schatz, Pichot, Delair, Viton, \& Domard, 2003; Sorlier, Rochas, Morfin, Viton, \& Domard, 2003). With these methods, we can determine the $M_{w}$ of a chitosan sample; therefore, we must have the values of refractive index increment $(d n / d C)$, which can be obtained by differential refractometry (Domard \& Rinaudo, 1983; Kasaai et al., 2000).

The measures of this method are influenced by the characteristics of the sample, such as formation of aggregates and DD. The formation of aggregates perturbs the molecular weight determination by light scattering. The DD leads to different behavior of the sample in response to light, and consequently, the critical $\mathrm{pH}$ and $\mathrm{pKa}$ are modified (Domard and Rinaudo, 1983). 


\section{Scanning electron microscopy (SEM)}

To investigate the morphology and structural details of chitosan, scanning electron microscopy (SEM) has been widely used.

SEM was used to study the morphology of $\alpha$ - and $\beta$ chitin. $\alpha$-chitin presents a laminar and dense structure, while the structure of $\beta$-chitin is completely different, with a surface less crystalline (Al Sagheer et al., 2009).

In a study conducted by Fernández Cervera et al. (2004), the structures of chitosans derived from lobster chitin before and after pulverization were characterized using SEM; irregular and amorphous particles with a size of $2000 \mu \mathrm{m}$ and $20 \mu \mathrm{m}$ for the non-pulverized and pulverized samples were observed.

The photographs of chitosan samples from silkworm obtained using a SEM showed that the structure was greatly porous (Paulino et al., 2006).

\section{$X$-ray diffraction (XRD)}

Clark and Smith (1936) established for the first time the X-ray fiber diffraction pattern of the hydrated (tendon) polymorph of chitosan. Several works revealed that the function of chitosan depends on its polymorphs (Ogawa, 1991). It is known that chitin shows various crystal modifications in nature. The usual conformation is the $\alpha$-chitin, typical of crustaceans and arthropods (Carlstrom, 1957). Other conformations are $\beta$-chitin and $\gamma$-chitin, differentiated by the position of adjacent chitin chains (Chebotok, Novikov, \& Konovalova, 2007).

Chitosan is also crystalline, but its structure is different from either $\alpha$-, $\beta$ - or $\gamma$-chitin as evidenced by the X-ray diffraction (XRD) patterns (Kurita, 2006). The crystal structures have been refined for the anhydrous and hydrated forms (Okuyama, Noguchi, Miyazawa, Yui, \& Ogawa, 1997; Yui et al., 1994).

Crystallinity degree $\left(\chi_{\mathrm{cr}}\right)$, is determined by the integral intensity of the peak of the crystalline regions in the diffraction pattern to the total peak (Abdou et al., 2008; Gorbacheva, Ovchinnikov, Y.K., Gal'braikh, L.S., Trofimov, N.A., \& Mazhorov, 1998; JCPDS, 1988). To calculate the intensity of the peak caused by the crystalline regions of the samples, the total area under the diffraction curve $\left(S_{\text {tot }}\right)$ and the area of the amorphous component $\left(S_{\mathrm{am}}\right)$ were determined graphically in the angle range that we choose.

Then, $\chi_{\mathrm{cr}}$ is calculated by the equation (Chebotok et al., 2007):

$$
\chi_{\mathrm{cr}}=\frac{S_{\mathrm{tot}}-S_{\mathrm{am}}}{S_{\mathrm{tot}}} \times 100
$$

Usually, chitins and chitosans have two crystalline peaks that range between $2 \theta=8.8-10.7^{\circ}$ and $2 \theta=18.8-20.7^{\circ}$ (Cardenas, Carbrera, Taboada, \& Miranda, 2004; Gartner et al., 2010; Kim et al., 1996; Prashanth, Kittur, \& Tharanathan, 2002; Yen \& Mau, 2004; Yen \& Mau, 2007a; Yen \& Mau, 2007b; Yen, Yang, \& Mau, 2009).
But, other authors found other peaks in some samples of chitin or chitosan like Yen and Mau (2007b) and Jang, Kong, Jeong, Lee, and Nah (2004).

Electron diffractometry is also a powerful tool for studying the molecular and crystal structures of chitosan (Mazeau, Winter, \& Chanzy, 1994).

\section{Membrane osmometry}

Using this method, the number average molecular weight $\left(M_{n}\right)$ could be determined due to the fall in osmotic pressure between the two sides of the membranes. The great advantage of this method is its insensitivity to large aggregates, which is useful in chitosans (Domard \& Rinaudo, 1983).

According to Flory (1953), the equation for determining $M_{n}$ represents the fall of osmotic pressure $(\pi / C)$ vs. the concentration, which yielded a straight line whose intercept provided $R T / M_{n}$ :

$$
\pi / C=R T\left(\frac{1}{M_{n}}+A_{2} C\right)
$$

where $R$ is the universal gas constant, $T$ is the absolute temperature, and $A_{2}$ is the second viral coefficient (Gamzazade et al., 1985; Kasaai et al., 2000).

\section{Applications: Active food packaging based on chitosan}

Due to the growing consumers' demands for quality, healthy, and safe food products, in the past years, different packaging strategies have been investigated to satisfy the industry as well as the consumers' requirements. Among them, films with antimicrobial properties appear as a promising approach. As mentioned previously, owing to the exceptional properties exhibited by chitosan, this polysaccharide makes an excellent candidate to be used in food packaging (Appendini \& Hotchkiss, 2002). An overview of bioactive materials based on chitosan and their main applications is presented in Supplementary Table 1.

\section{Supplementary material}

The supplementary material for this paper is available online at http://dx.doi.org/10.1080/19476337.2011.603844

\section{Acknowledgements}

This work was funded under the Project no. 95935 from FONCICYT C002-2008-1/ALA 127249.

\section{References}

Abdou, E.S., Nagy, K.S.A., \& Elsabee, M.Z. (2008). Extraction and characterization of chitin and chitosan from local sources. Bioresource Technology, 99, 13591367.

Aiba, S. (1986). Studies on chitosan: 1. Determination of the degree of $\mathrm{N}$-acetylation of chitosan by ultraviolet spectrophotometry and gel permeation chromatography. International Journal of Biological Macromolecules, 8, 173-176. 
AlSagheer, F.A., Al-Sughayer, M.A., Muslim, S., \& Elsabee, M.Z. (2009). Extraction and characterization of chitin and chitosan from marine sources in Arabian Gulf. Carbohydrate Polymers, 77, 410-419.

Anthonsen, M.W., Vårum, K.M., \& Smidsrød, O. (1993). Solution properties of chitosans: Conformation and chain stiffness of chitosans with different degrees of N-acetylation. Carbohydrate Polymers, 22, 193-201.

Appendini, P., \& Hotchkiss, J.H. (2002). Review of antimicrobial food packaging. Innovative Food Science \& Emerging Technologies, 3, 113-126.

Arcidiacono, S., \& Kaplan, D.L. (1992). Molecular weight distribution of chitosan isolated from Mucor rouxii under different culture and processing conditions. Biotechnology and Bioengineering, 39, 281-286.

Balázs, N., \& Sipos, P. (2007). Limitations of pH-potentiometric titration for the determination of the degree of deacetylation of chitosan. Carbohydrate Research, 342, 124-130.

Belalia, R., Grelier, S., Benaissa, M., \& Coma, V. (2008). New bioactive biomaterials based on quaternized chitosan. Journal of Agricultural Food Chemistry, 56, 1582-1588.

Broussignac, P. (1968). Chitosan: A natural polymer not well known by the industry. Chemie Industriel Genie Chimie, 99, 1241-1247.

Brugnerotto, J., Lizardi, J., Goycoolea, F.M., ArgüellesMonal, W., Desbrières, J., \& Rinaudo, M. (2001). An infrared investigation in relation with chitin and chitosan characterization. Polymer, 42, 3569-3580.

Cai, J., Yang, J., Du, Y., Fan, L., Qiu, Y., Li, J., \& Kennedy, J.F. (2006). Purification and characterization of chitin deacetylase from Scopulariopsis brevicaulis. Carbohydrate Polymers, 65, 211-217.

Cardenas, G., Carbrera, G., Taboada, E., \& Miranda, S.P (2004). Chitin characterization by SEM, FTIR, XRD, and $13 \mathrm{C}$ cross polarization/mass angle spinning NMR. Journal of Applied Polymer Science, 93, 1876-1885.

Carlstrom, D. (1957). The crystal structure of $\alpha$-chitin. The Journal of Biophysical and Biochemical Cytology, 3 , 669-683.

Chebotok, E.N., Novikov, V.Y., \& Konovalova, I.N. (2007). Kinetics of base deacetylation of chitin and chitosan as influenced by their crystallinity. Russian Journal of Applied Chemistry, 80, 1753-1758.

Clark, G.L., \& Smith, A.F. (1936). X-ray diffraction studies of chitin, chitosan, and derivatives. The Journal of Physical Chemistry, 40, 863-879.

Curotto, E., \& Aros, F. (1993). Quantitative determination of chitosan and the percentage of free amino groups. Analytical Biochemistry, 211, 240-241.

de Alvarenga, E.S., de Oliveira, C.P., \& Bellato, C.R. (2010). An approach to understanding the deacetylation degree of chitosan. Carbohydrate Polymers, 80, 1155-1160.

Domard, A., \& Rinaudo, M. (1983). Preparation and characterization of fully deacetylated chitosan. International Journal of Biological Macromolecules, 5, 49-52.

Donald, H.D., \& Hayes, E.R. (1988). Determination of degree of acetylation of chitin and chitosan. Methods in Enzymology, 161, 442-446.

dos Santos, Z.M., Caroni, A.L.P.F., Pereira, M.R., da Silva, D.R., \& Fonseca, J.L.C. (2009). Determination of deacetylation degree of chitosan: A comparison between conductometric titration and $\mathrm{CHN}$ elemental analysis. Carbohydrate Research, 344, 2591-2595.

Duarte, M.L., Ferreira, M.C., Marvão, M.R., \& Rocha, J. (2002). An optimised method to determine the degree of acetylation of chitin and chitosan by FTIR spectroscopy. International Journal of Biological Macromolecules, 31, $1-8$.
Dutta, P.K., Tripathi, S., Mehrotra, M.K., \& Dutta, J. (2009). Perspectives for chitosan based antimicrobial films in food applications. Food Chemistry, 114, 11731182 .

Errington, N., Harding, S.E., Vårum, K.M., \& Illum, L. (1993). Hydrodynamic characterization of chitosans varying in degree of acetylation. International Journal of Biological Macromolecules, 15, 113-117.

Fajardo, P., Martins, J.T., Fuciños, C., Pastrana, L., Teixeira, J.A., \& Vicente, A.A. (2010). Evaluation of a chitosan-based edible film as carrier of natamycin to improve the storability of Saloio cheese. Journal of Food Engineering, 101, 349-356.

Fernández Cervera, M., Heinämäki, J., Räsänen, M., Maunu, S.L., Karjalainen, M., Nieto Acosta, O.M., ... Yliruusi, J. (2004). Solid-state characterization of chitosans derived from lobster chitin. Carbohydrate Polymers, 58, 401-408.

Fimbeau, S., Grelier, S., Copinet, A., \& Coma, V. (2006). Novel biodegradable films made from chitosan and poly(lactic acid) with antifungal properties against mycotoxinogen strains. Carbohydrate Polymers, 65, 185-193.

Fisk, C.L., Silver, A.M., Strik, B.C., \& Zhao, Y. (2008). Postharvest quality of hardy kiwifruit (Actinidia arguta 'Ananasnaya') associated with packaging and storage conditions. Postharvest Biology and Technology, 47, 338-345.

Flory, P.J. (1953). Principles of polymer chemistry. Ithaca, NY.

Gamzazade, A.I., Slimak, V.M., Skljar, A.M., Stykova, E.V., Pavlova, S.S.A., \& Rogozin, S.V. (1985). Investigation of the hydrodynamic properties of chitosan solutions. Acta Polymerica, 36, 420-424.

Gartner, C., Peláez, C.A., \& López, B.L. (2010). Characterization of chitin and chitosan extracted from shrimp shells by two methods. e-Polymers, 69, 1-16.

Gorbacheva, I.N., Ovchinnikov, Y.K., Gal'braikh, L.S., Trofimov, N.A., \& Mazhorov, V.V. (1998). An X-ray study of the structure of chitosan. Polymer Science USSR, 30, 2694-2698.

Guaita, M., Chiantore, O., Munari, A., Manaresi, P., Pilati, F., \& Toselli, M. (1991). A general intrinsic viscositymolecular weight relationship for linear polydisperse polymers - 3. Applicability to the evaluation of the Mark-Houwink-Sakurada k and a constants. European Polymer Journal, 27, 385-388.

Guinesi, L.S., \& Gomes Cavalheiro, E.T. (2006). The use of DSC curves to determine the acetylation degree of chitin/ chitosan samples. Thermochimica Acta, 444, 128-133.

Gyliene, O., Rekertas, R., \& Salkauskas, M. (2002). Removal of free and complexed heavy-metal ions by sorbents produced from fly (Musca domestica) larva shells. Water Research, 36, 4128-4136.

Hoagland, P.D., \& Parris, N. (1996). Chitosan/pectin laminated films. Journal of Agriculture and Food Chemistry, 44, 1915-1919.

Hong, P.Z., Li, S.D., Ou, C.Y., Li, C.P., Yang, L., \& Zhang, C.H. (2007). Thermogravimetric analysis of chitosan. Journal of Applied Polymer Science, 105, 547-551.

Inukai, Y., Chinen, T., Matsuda, T., Kaida, Y., \& Yasuda, S. (1998). Selective separation of germanium(IV) by 2,3dihydroxypropyl chitosan resin. Analytica Chimica Acta, 371, 187-193.

Jang, M.K., Kong, B.G., Jeong, Y.I., Lee, C.H., \& Nah, J.W. (2004). Physicochemical characterization of $\alpha$-chitin, $\beta$-chitin, and $\gamma$-chitin separated from natural resources. Journal of Polymer Science Part A: Polymer Chemistry, 42, 3423-3432.

JCPDS (Joint Committee on Powder Diffraction Standards) (1988). International centre for diffraction data. PCPDFWIN, ver. 2.00 . 
Kasaai, M.R. (2008). A review of several reported procedures to determine the degree of $N$-acetylation for chitin and chitosan using infrared spectroscopy. Carbohydrate Polymers, 71, 497-508.

Kasaai, M.R. (2009). Various methods for determination of the degree of $\mathrm{N}$-acetylation of chitin and chitosan: A review. Journal of Agriculture and Food Chemistry, 57, 1667-1676.

Kasaai, M.R., Arul, J., \& Charlet, G. (2000). Intrinsic viscosity - molecular weight relationship for chitosan. Journal of Polymer Science Part B: Polymer Physics, 38, 2591-2598.

Kasaai, M.R., Arul, J., Chin, S.L., \& Charlet, G. (1999). The use of intense femtosecond laser pulses for the fragmentation of chitosan. Journal of Photochemistry and Photobiology A: Chemistry, 120, 201-205.

Khan, T.A., Peh, K.K., \& Ch'ng, H.S. (2002). Reporting degree of deacetylation values of chitosan: The influence of analytical methods. Journal of Pharmacy and Pharmaceutical Sciences, 5, 205-212.

Kim, H.S. (2004). Thermodynamic studies of interaction between chitosan and metal ions by isothermal titration calorimetry (I). Journal of Industrial and Engineering Chemistry, 10, 273-277.

Kim, S.S., Kim, S.H., \& Lee, Y.M. (1996). Preparation, characterization, and properties of $\beta$ chitin and $\mathrm{N}$-acetylated $\beta$ chitin. Journal of Polymer Science Part B: Polymer Physics, 34, 2367-2374.

Kjøniksen, A.L., Iversen, C., Nyström, B., Nakken, T., \& Palmgren, O. (1998). Light scattering study of semidilute aqueous systems of chitosan and hydrophobically modified chitosans. Macromolecules, 31, 81428148 .

Kucukgulmez, A., Celik, M., Yanar, Y., Sen, D., Polat, H., \& Kadak, A.E. (2011). Physicochemical characterization of chitosan extracted from Metapenaeus stebbingi shells. Food Chemistry, 126, 1144-1148.

Kurita, K. (2006). Chitin and chitosan: Functional biopolymers from marine crustaceans. Marine Biotechnology, 8 , 203-226.

Lavertu, M., Xia, Z., Serreqi, A.N., Berrada, M., Rodriques, A., Wang, A.D., ... Gupta, A. (2003). A validated 1H NMR method for the determination of the degree of deacetylation of chitosan. Journal of Pharmaceutical and Biomedical Analysis, 32, 1149-1158.

Li, J., Du, Y., Yang, J., Feng, T., Li, T., \& Chen, P. (2005). Preparation and characterisation of low molecular weight chitosan and chito-oligomers by a commercial enzyme. Polymer Degradation and Stability, 87, 441-448.

Lim, S.H., \& Hudson, S.M. (2004). Synthesis and antimicrobial activity of a water-soluble chitosan derivative with a fiber-reactive group. Carbohydrate Research, 339, 313-319.

Liu, H., Bao, J., Du, Y., Zhou, X., \& Kennedy, J.F. (2006). Effect of ultrasonic treatment on the biochemphysical properties of chitosan. Carbohydrate Polymers, 64, 553559.

López, F.A., Mercè, A.L.R., Alguacil, F.J., \& LópezDelgado, A. (2008). A kinetic study on the thermal behavior of chitosan. Journal of Thermal Analysis and Calorimetry, 91, 633-639.

Ma, G., Qian, B., Yang, J., Hu, C., \& Nie, J. (2010). Synthesis and properties of photosensitive chitosan derivatives (1). International Journal of Biological Macromolecules, 46, 558-561.

Manaresi, P., Munari, A., Pilati, F., \& Marianucci, E. (1998). A general intrinsic viscosity-molecular weights relationship for polydisperse polymers. European Polymer Journal, 24, 575-578.
Mazeau, K., Winter, W.T., \& Chanzy, H. (1994). Molecular and crystal structure of a high-temperature polymorph of chitosan from electron diffraction data. Macromolecules, 27, 7606-7612.

Mima, S., Miya, M., Iwamoto, R., \& Yoshikawa, S. (1983). Highly deacetylated chitin and its properties. Journal of Applied Polymer Science, 28, 1909-1917.

Moller, H., Grelier, S., Pardon, P., \& Coma, V. (2004). Antimicrobial and physicochemical properties of chitosan-HPMC-based films. Journal of Agricultural Food Chemistry, 52, 6585-6591.

Muzzareli, R.A.A., Muzzarelli, C., Tarsi, R., Miliani, M., Gabbanelli, F., \& Cartolari, M. (2001). Fungistatic activity of modified chitosans against Saprolegnia parasitica. Biomacromolecules, 2, 165-169.

Neto, C.G.T., Giacometti, J.A., Job, A.E., Ferreira, F.C., Fonseca, J.L.C., \& Pereira, M.R. (2005). Thermal analysis of chitosan based networks. Carbohydrate Polymers, 62, 97-103.

Nguyen, S., Hisiger, S., Jolicoeur, M., Winnik, F.M., \& Buschmann, M.D. (2009). Fractionation and characterization of chitosan by analytical SEC and ${ }^{1} \mathrm{H}$ NMR after semi-preparative SEC. Carbohydrate Polymers, 75, 636-645.

Ogawa, K. (1991). Effect of heating an aqueous suspension of chitosan on the crystallinity and polymorphs. Agricultural and Biological Chemistry, 55, 2375-2379.

Ojagh, S.M., Rezaei, M., Razavi, S.H., \& Hosseini, S.M.H. (2010). Development and evaluation of a novel biodegradable film made from chitosan and cinnamon essential oil with low affinity toward water. Food Chemistry, 122, 161-166.

Okuyama, K., Noguchi, K., Miyazawa, T., Yui, T., \& Ogawa, K. (1997). Molecular and crystal structure of hydrated chitosan. Macromolecules, 30, 5849-5855.

Ottøy, M.H., Vårum, K.M., Christensen, B.E., Anthonsen, M.W., \& Smidsrød, O. (1996). Preparative and analytical size-exclusion chromatography of chitosans. Carbohydrate Polymers, 31, 253-261.

Pa, J.H., \& Yu, T.L. (2001). Light scattering study of chitosan in acetic acid aqueous solutions. Macromolecular Chemistry and Physics, 202, 985-991.

Paulino, A.T., Simionato, J.I., Garcia, J.C., \& Nozaki, J. (2006). Characterization of chitosan and chitin produced from silkworm crysalides. Carbohydrate Polymers, 64, 98103.

Pawlak, A., \& Mucha, M. (2003). Thermogravimetric and FTIR studies of chitosan blends. Thermochimica Acta, 396, 153-166.

Pochanavanich, P., \& Suntornsuk, W. (2002). Fungal chitosan production and its characterization. Letters in Applied Microbiology, 35, 17-21.

Pogodina, N.V., Pavlov, G.M., Bushin, S.V., Mel'Nikov, A.B., Lysenko, Y.B., Nud'Ga, L.A., ... Tsvetkov, V.N. (1986). Conformational characteristics of chitosan molecules as demonstrated by diffusion-sedimentation analysis and viscosimetry. Polymer Science USSR, 28, 251-259.

Popa, M.I., Lisa, G., \& Aelenei, N. (2008). Thermogravimetric characterization of chitosan/alginate microparticles loaded with different drugs. Polymer Bulletin, 61, 481-490.

Pourjavadi, A., Mahdavinia, G.R., Zohuriaan-Mehr, M.J., \& Omidian, H. (2003). Modified chitosan. I. Optimized cerium ammonium nitrate-induced synthesis of chitosangraft-polyacrylonitrile. Journal of Applied Polymer Science, 88, 2048-2054.

Prashanth, K.V.H., Kittur, F.S., \& Tharanathan, R.N. (2002). Solid state structure of chitosan prepared under different N-deacetylating conditions. Carbohydrate Polymers, 50, 27-33. 
Prochazkova, S., Vårum, K.M., \& Ostgaard, K. (1999). Quantitative determination of chitosans by ninhydrin Carbohydrate Polymers, 38, 115-122.

Rao, D.G. (1993). Studies on viscosity-molecular weight relationship of chitosan solutions. Journal of Food Science and Technology, 30, 66-67.

Ribeiro, C., Vicente, A.A., Teixeira, J.A., \& Miranda, C. (2007). Optimization of edible coating composition to retard strawberry fruit senescence. Postharvest Biology and Technology, 44, 63-70.

Rinaudo, M. (2006). Chitin and chitosan: Properties and applications. Progress in Polymer Science, 31, 603-622.

Rinaudo, M., Milas, M., \& Dung, P.L. (1993). Characterization of chitosan. Influence of ionic strength and degree of acetylation on chain expansion. International Journal of Biological Macromolecules, 15, 281-285.

Roberts, G.A.F., \& Domszy, J.G. (1982). Determination of the viscometric constants for chitosan. International Journal of Biological Macromolecules, 4, 374-377.

Rogovina, S.Z., Akopova, T.A., \& Vichoreva, G.A. (1998). Investigation of properties of chitosan obtained by solidphase and suspension methods. Journal of Applied Polymer Science, 70, 927-933.

Rosca, C., Popa, M.I., Lisa, G., \& Chitanu, G.C. (2005). Interaction of chitosan with natural or synthetic anionic polyelectrolytes. 1 . The chitosan-carboxymethylcellulose complex. Carbohydrate Polymers, 62, 35-41.

Rúnarsson, O.V., Holappa, J., Malainer, C., Steinsson, H., Hjálmarsdóttir, M., Nevalainen, T., \& Másson, M. (2010). Antibacterial activity of N-quaternary chitosan derivatives: Synthesis, characterization and structure activity relationship (SAR) investigations. European Polymer Journal, 46, 1251-1267.

Sannan, T., Kurita, K., \& Iwakura, Y. (1976). Studies on chitin, 2: Effect of deacetylation on solubility. Makromolekulare Chemie, 177, 3589-3600.

Schatz, C., Pichot, C., Delair, T., Viton, C., \& Domard, A. (2003). Static light scattering studies on chitosan solutions: From macromolecular chains to colloidal dispersions. Langmuir, 19, 9896-9903.

Sebti, I., Chollet, E., Degraeve, P., Noel, C., \& Peyrol, E. (2007). Water sensitivity, antimicrobial, and physicochemical analyses of edible films based on HPMC and/or chitosan. Journal of Agricultural Food Chemistry, 55, 693-699.

Shigemasa, Y., Matsuura, H., Sashiwa, H., \& Saimato, H. (1996). Evaluation of different absorbance ratios from infrared spectroscopy for analyzing the degree of deacetylation in chitin. International Journal of Biological Macromolecules, 18, 237-242.

Song, Q., Zhang, Z., Gao, J., \& Ding, C. (2011). Synthesis and property studies of $\mathrm{N}$-carboxymethyl chitosan. Journal of Applied Polymer Science, 119, 3282-3285.

Sorlier, P., Rochas, C., Morfin, I., Viton, C., \& Domard, A. (2003). Light scattering studies of the solution properties of chitosans of varying degrees of acetylation. Biomacromolecules, 4, 1034-1040.

Taboada, E., Cabrera, G., \& Cárdenas, G. (2004). Synthesis and characterization of new arylamine chitosan derivatives. Journal of Applied Polymer Science, 91, 807-812.

Tan, S.C., Khor, E., Tan, T.K., \& Wong, S.M. (1998). The degree of deacetylation of chitosan: Advocating the first derivative UV-spectrophotometry method of determination. Talanta, 45, 713-719.

Tanford, C. (1961). Physical chemistry of macromolecules. New York: Wiley.
Van Toan, N. (2009). Production of chitin and chitosan from partially autolyzed shrimp shell materials. The Open Biomaterials Journal, 1, 21-24.

Vårum, K.J., Egelandsdal, B., \& Ellekjaer, M.R. (1995). Characterization of partially $N$-acetylated chitosans by near infra-red spectroscopy. Carbohydrate Polymers, 28 , 187-193.

Wang, J., Jin, X., \& Chang, D. (2009). Chemical modification of chitosan under high-intensity ultrasound and properties of chitosan derivatives. Carbohydrate Polymers, 78 , 175-177.

Wang, W., Bo, S., Li, S., \& Qin, W. (1991). Determination of the Mark-Houwink equation for chitosans with different degrees of deacetylation. International Journal of Biological Macromolecules, 13, 281-285.

Wang, X., \& Liu, H. (2004). Preparation, characterization and antimicrobial activity of chitosan- $\mathrm{Zn}$ complex. Carbohydrate Polymers, 56, 21-26.

Wei, X., Cruz, J., \& Gorski, W. (2002). Integration of enzymes and electrodes: Spectroscopic and electrochemical studies of chitosan-enzyme films. Analytical Chemistry, 74, 5039-5046.

Wong, D.W.S., Gastineau, F.A., Gregorski, K.S., Tillin, S.J., \& Pavlath, A.E. (1992). Chitosan-lipid films: Microstructure and surface energy. Journal of Agriculture and Food Chemistry, 40, 540-544.

Xie, W., Xu, P., Wang, W., \& Liu, Q. (2002). Preparation and antibacterial activity of a water-soluble chitosan derivative. Carbohydrate Polymers, 50, 35-40.

Yang, T.Ch., Chou, Ch.Ch., \& Li, Ch.F. (2005). Antibacterial activity of $\mathrm{N}$-alkylated disaccharide chitosan derivatives. International Journal of Food Microbiology, 97, 237-245.

Yen, M.T., \& Mau, J.L. (2004). Physico-chemical properties of chitin from shiitake stipes and crab shells. Annual of Tainan Woman's College of arts and Technology, 23, 229-240.

Yen, M.T., \& Mau, J.L. (2007a). Physico-chemical characterization of fungal chitosan from shiitake stipes. LWT-Food Science and Technology, 40, 472-479.

Yen, M.T., \& Mau, J.L. (2007b). Selected physical properties of chitin prepared from shiitake stipes. LWT-Food Science and Technology, 40, 558-563.

Yen, M.T., Yang, J.H., \& Mau, J.L. (2009). Physicochemical characterization of chitin and chitosan from crab shells. Carbohydrate Polymers, 75, 15-21.

Yomota, C., Miyazaki, T., \& Okada, S. (1993). Determination of the viscometric constants for chitosan and the application of universal calibration procedure in its gel permeation chromatography. Colloid \& Polymer Science, $271,76-82$

Yui, T., Imada, K., Okuyama, K., Obata, Y., Suzuki, K., \& Ogawa, K. (1994). Molecular and crystal structure of the anhydrous form of chitosan. Macromolecules, 27, $7601-7605$.

Zhang, Y., Xue, C., Xue, Y., Gao, R., \& Zhang, X. (2005). Determination of the degree of deacetylation of chitin and chitosan by X-ray powder diffraction. Carbohydrate Research, 340, 1914-1917.

Zhang, Y., Zhang, X., Ding, R., Zhang, J., \& Liu, J. (2011). Determination of the degree of deacetylation of chitosan by potentiometric titration preceded by enzymatic pretreatment. Carbohydrate Polymers, 83, 813-817. 